\title{
Internet Freedom of Speech and Privacy Protection: \\ Is There a Contradiction? (A Study of Rating Sites)
}

\section{凡目 Elena Ostanina}

Associate Professor, Department of Civil Law and Process, Law Institute, Chelyabinsk State University, Candidate of Juridical Sciences. Address: $129 \mathrm{Br}$. Kashirinyh Avenue, Chelyabinsk 454080, Russian Federation. E-mail: elenaostanina@mail.ru

\section{睢目 Abstract}

While the Internet promotes widespread communication, this communication is often anonymous. How to draw the line between freedom of speech and privacy? The specifics of protecting privacy and business reputation against violation by rating sites are discussed in this article. Do the activities of rating sites need special legal regulation? The author believes that the general rules on privacy and freedom of speech are sufficient for regulating these new relations. The respective court practice of Germany, the UK and the USA is analysed. The tentative conclusion is that rating sites do not contradict the law if they do not disseminate information about the private lives of people or encourage rude and scornful assessments. The problem of using personal data is examined. The author holds the view that the activities of rating sites can be beneficial for society and therefore should not be banned entirely. However, site owners should be allowed to use personal data only upon the consent of the owners of the latter.

\section{요 Keywords}

freedom of speech, reputation protection, privacy, site, damage, site owner.

For citation: Ostanina E.A. (2020) Internet Freedom of Speech and Privacy Protection: Is There a Contradiction? (A Study of Rating Sites) // Legal Issues in the Digital Age, no 3, pp. $125-139$.

DOI: $10.17323 / 2713-2749.2020 .3 .125 .139$

\section{Introduction}

Uber was apparently the first Internet platform to introduce a rating system. This system provides a convenient means of assessing the quality of services. Today, many organizations offer ratings of their employees, while some organizations, including Uber, also provide ratings of their customers. 
The spread of ratings is facilitated by social networks with theirs system of "likes" and "dislikes" and subscriber metrics. Ratings are common both in professional activities (ratings of restaurants, cafes, schools, universities and sites) and in interpersonal relations.

Many specialists such as medical doctors, teachers, and lawyers are being rated today, often without knowing anything about it.

In Russia ratings have not been the subject of litigation so far, although official and unofficial ratings have evoked a lot of emotions (both positive and negative). In foreign civil proceedings, rating sites have been subjected to evaluation on several occasions. Let us consider this experience in more detail.

\section{Privacy protection versus freedom of speech: a general characteristic}

People living in the digital age are not ready to part with confidentiality and the secrets of private life [Roessler B., 2005: 62]. Still, maintaining confidentiality is somewhat more difficult on account of the digital traces left by every person. Messages remain after communication on Internet forums, and photos are posted on social networks. All this information is stored for a long time after being posted. The author of such information may subsequently change his or her mind, yet it will take a lot of time and effort to remove it from the Internet. Even if an individual is careful, third parties can post unwanted information. This aspect of privacy protection needs careful analysis. Such significant freedoms as the freedom of speech and the right to privacy interact here. Freedom of speech is a right that does not have clear boundaries established in advance. The boundaries of this right are delineated on a case-by-case basis. The values that can be violated during the exercise of the freedom of speech and the values that should be protected must be compared. There are strict guidelines for this, of course. In particular, the dissemination of false information discrediting honour, dignity and business reputation is not allowed.

\section{Germany: Spickmich judgment (2009) - assessments and the freedom of speech}

In Germany an extensive and controversial practice has already developed with respect to the legitimacy of rating sites. This practice began with a lawsuit by a school teacher who believed that her privacy had been violated by a site on which users compared schools (www.spickmich.de).

The circumstances of the case were as follows: the defendants developed an online website for schoolchildren, where teachers and teaching in various German 
schools were discussed. The site www.spickmich.de kept and posted information about the names of teachers, the names of schools, the subjects taught, student ratings of teachers, and quotes by teachers. This information was accessible to registered site users. Registration on the site required entering the correct name of a school, the location of the school, a username and an email address. Registration was confirmed by a link sent to the indicated email. Users could share information about themselves, send messages to other users or create their own "clubs" or groups of "friends" and "classmates" on different pages of the site. The site had the rubrics "my page", "my friends", "news", and "my city".

However, the subject of controversy was the rubric "my school". On the site, users could evaluate their school building, equipment, extracurricular activities and teachers. When evaluating teachers, one could use predefined criteria such as "cool and funny" (cool und witzig), "popular" (beliebt), "knows how to motivate", "humane", "good lessons", "fair grades", "appearance”, etc.

It was possible to rate all the criteria or several of them, albeit not less than four, on a scale of one to six points. The teacher's overall assessment was a sum of his or her individual ratings. The evaluation result was displayed in the form of a certificate that could be printed out. In addition, users could write quotes of their teachers in the "Quotes" section. If no new ratings appeared for a teacher in 12 months, the old grades and quotes were automatically deleted. The message "there is a contradiction" appeared on the site when the ratings of several users significantly differed from each other.

In early May 2007, the plaintiff discovered that a certificate with her name, the name of the school in which she taught, and her subject (German) had been posted on the website www.spickmich.de. The certificate was based on four student ratings and indicated an overall score of $4.3^{1}$. No quotes were given. The name, school and subject were indicated on the website in exactly the same way as on the school's open-access website.

In her lawsuit, the teacher demanded that her name and information be removed from spickmich.de.

The court rejected the lawsuit ${ }^{2}$. The Court of Appeal agreed with the decision of the trial court, arguing that the assessments made by the defendant constituted an expression of opinion and that the plaintiff's personal non-property rights had not been violated, since all the assessments related to her professional activities.

Criteria such as a teacher's sense of humour ("cool and funny"), appearance, and humane attitude also related to the professional qualities of the plaintiff, since a person must control his or her speech and behaviour in professional activities.

${ }^{1}$ In German schools, the maximum score is usually 1 , so a score of 4.3 is apparently quite low.

2 Available at: https://dejure.org/dienste/vernetzung/rechtsprechung?Gericht=BGH\&Datum= 23.06.2009\&Aktenzeichen=VI\%20ZR\%20196\%2F08// (accessed: 20.09.2020) 
In such activities, it is also important to see the consequences of one's actions and their perception by others. Ratings can serve as a guide for schoolchildren and parents, as well as increasing transparency.

The Court of Appeal further noted that, insofar as teachers give grades to students, students should also be allowed to rate teachers.

The rules of registration on the site ensured that the site was used only by interested parties whom this information concerned in one way or another - students, parents and teachers. The rating page could not be found by entering the teacher's name in an Internet search.

The anonymity of the assessment also assured the legality of the publication. Legislation in force at this time allowed the anonymous use of the Internet.

In the learning process, students depend on teachers and their grades. This makes the anonymity of the reviews justified: otherwise, students could fear negative consequences.

The system of registration on the site means that the owner of the site could take measures against inappropriate, offensive, false or defamatory statements. Therefore, the anonymity of publications was justified. As for the teachers' quotes published on the site, no false quotes had ever been identified. It cannot be said that any personal data of the plaintiff was disclosed, since the name of the teacher, the name of the school and the subjects that the teacher taught could easily be obtained from the school's open website.

In its decision \#VI ZR 196/08 of June 23, 2009, the German Supreme Court upheld all the arguments of the court of appeal as well as emphasizing the admissibility of the collection, storage and transmission of personal data as part of a rating forum on the Internet ${ }^{3}$.

The sixth composition of the German Supreme Court examined in great detail the arguments of both the plaintiff and the defendant, making the Spickmich case a significant precedent for the development of the theory of privacy and the freedom of speech.

The German Supreme Court noted that the defendant (the owner of the site) provided an information and communication service. The defendant was not responsible for information posted by third parties. He would have been responsible if he had known about the illegality of the information, yet, in this case, such illegality was not evident. It is true that the plaintiff did not give permission to collect and use her personal data. However, the site reflected only limited information about the plaintiff that was already freely available on the school's website. The defendant did not try to take personal advantage of this data; he processed it automatically by calculating the average score of ratings given by users.

${ }^{3}$ German Supreme Court Decision \#VI ZR 196/08, June 6, 2009. Available at: https://dejure. org/dienste/vernetzung/rechtsprechung?Gericht=BGH\&Datum=23.06.2009\&Aktenzeichen= VI\%20ZR\%20196\%2F08 (accessed: 10.09.2020) 
When considering the use of the personal data of the plaintiff, the judges cited several legal sources. These sources showed that sites that rate specialists enjoy the privileges of mass media and are allowed to collect all necessary information for the rating, including personal data from open sources. Information can be collected from open sources without the consent of individuals to whom the information relates; otherwise, journalistic activity would become impossible.

The decisive criterion for the judgment was that personal data was used only to create a news message (in this case, a rating).

One should use only information without which the news message or rating cannot be created.

Personal information should not be used simply to embellish news or evoke emotions. However, in the present case, personal data had been used in a "modest" fashion.

Further, the court decision discussed the question of whether the defendant had taken a legitimate interest in the storage and processing of the plaintiff's personal data.

The German Supreme Court ruled that the site's activities met public demand for information about schools.

The court also noted that the defendant reasonably limited the dissemination of information - site users could see information about teachers and schools, including reviews and ratings, while third parties not registered on the site could not.

To the question of whether the ratings and reviews violated the plaintiff's privacy rights, the court replied in the negative. There was no violation, since communication with students did not pertain to the private life of the plaintiff.

Everyone has the right to decide what to do with his or her personal data (this is what the German Armed Forces calls the "right to informational self-determination"), but the desire for confidentiality should not be excessive.

Information related to private life is particularly protected, while information relating to professional activities, i.e., human interaction with society, cannot be absolutely confidential. Despite the fact that a number of assessments such as "sense of humour" and "humaneness" related to the personality of the plaintiff, they also reflected how the plaintiff behaved in the professional sphere. The ratings were not expressed in an offensive manner and did not affect the human dignity of the plaintiff. Therefore, while recognizing that ratings, reviews and Internet publications in general can threaten privacy, the German Supreme Court did not see a violation of the right to privacy in this case.

The court was not convinced by the plaintiff's argument that she had not registered on the site and that the ratings had been made by anonymous users. It decided that the right of site users to freely express their opinions was not contingent upon the plaintiff's registration on the site. 
The German Supreme Court agreed with the appellate court that the anonymity of ratings is acceptable on such sites. Otherwise, the freedom of speech would be limited by the fear of repression. The court also judged that the owners of the site showed reasonable discretion, providing the note "there is a contradiction" to draw attention to differences in ratings made by users.

The German Supreme Court emphasized that every reasonable user of the site was aware that the ratings could be biased. However, even biased assessments can be useful to people, including the teacher himself.

In view of all the above arguments, the court upheld the decisions of previous instances. The plea to exclude information about the plaintiff from the content of the rating site was denied.

This court decision was widely discussed in later literature [Barendt E., 2016: 112]; [Ungern-Sternberg S., 2019: 8-15].

The decision can be viewed in a positive light. Indeed, our competence as rational and social agents depends on a constructive adaptation of social control mechanisms [Schoeman F., 1992: 204]. The German judges who considered this case were credited with (1) creating the guideline that, in contrast to private life, official affairs and actions can be discussed, (2) justly drawing attention to the fact that records should be made available only to authorized site users, and (3) correctly defining the main problem that reviews and comments posted on the Internet can violate privacy [Cheung A., Schultz W., 2018: 332-335].

\section{Germany: two Jameda cases (2014 and 2016)}

Court practice in this domain was further developed in two cases involving the owner of the Jameda website. While these cases, which relate to ratings of doctors, are slightly less cited than the Spickmich case, they have also had a noticeable impact on the development of the theory of the protection of privacy on rating sites.

The first case led to German Supreme Court Decision \#VI ZR 358/13 of September 23, 2014. The Jameda website provided useful information about medical organizations in Germany and, in particular, allowed patients to rate the doctors they visited.

Individual ratings were combined to make doctor ratings. Only registered users were entitled to make ratings; registration required the confirmation of an email address.

The information about doctors posted on the site include their name, education, academic degree, specialization and place of work.

4 Available at: http://juris.bundesgerichtshof.de/cgi-bin/rechtsprechung/document.py?Gericht $=$ bgh\&Art $=$ en $\& n r=69297 \&$ pos $=0 \& a n z=1$ (accessed: 15.09 .2020$)$ 
The plaintiff (a gynaecologist), after learning that the site has information, including several ratings, about him, demanded that it be removed by the site owner. The latter refused.

The trial court dismissed the lawsuit, and the appellate court upheld the decision.

In the appeal, the plaintiff insisted that the defendant made illegal use of personal data. The plaintiff said in the cassation appeal that the defendant had used the personal data of doctors not only to the benefit of site users but also for commercial gain, since the defendant offered a paid service for promoting doctors' profiles. A site user who searched for a "gynaecologist" first saw the profiles of doctors who concluded agreements for promoting their profiles and only then the profiles of other doctors in the order of their rating.

The argument about the commercial use of personal data was very strong. However, the plaintiff did not submit this argument to the court of first instance, while higher courts do not consider new evidence. Therefore, the German Supreme Court rejected this argument for procedural reasons.

As a result, the arguments of the prosecution only cited the facts that the plaintiff had not allowed the use of his personal data, had not expressed his consent to being rated, and held the view that, in the absence of his consent, the respondent's website did not have the right to use information about him. In its assessment of these arguments, the German court noted the following.

First of all, the inclusion of the plaintiff in the doctors' rating without his consent violated the plaintiff's right to informational self-determination. In addition, the professional activities of the plaintiff had been seriously damaged by the information and ratings posted on the respondent's website. However, this violation was nothing more than a guarantee of the patient's rights to express his or her opinion freely. There is major public interest in making potential patients more aware about doctors to inform their choice. Patients at the stage of choosing doctor are vulnerable and do not always dispose of sufficient information. The site run by the defendant was designed to help patients make a choice.

Although the evaluations on the site did not paint a complete picture of treatment (since these evaluations were made by patients, not professionals), the opinions of other patients can also be important for a patient choosing a doctor.

Secondly, the site allowed people to rate and write reviews anonymously; however, such evaluations could only be made by registered users, and so the respondent had information about the evaluators' email addresses. In the event of inaccurate information or a review expressed in an offensive form, a person could file a complaint against the defendant, for which a special tab was provided on the site.

Thirdly and most importantly, the plaintiff demanded that information about him be deleted from the ranking of doctors on the respondent's website. If his claim had been satisfied, other doctors would most likely have requested not to 
be evaluated, either. This, in turn, would have put doctors who did not refuse to participate in the rating in a vulnerable position. They would have run the risk of negative reviews and competing with doctors about whom no reviews had appeared on the site.

In addition, if the site contained information about some doctors only, this would harm the very concept of the site and make it ineffective. The claim was denied.

In later practice, this case was interpreted as showing that sanctions should be proportionate and that it is undesirable to delete personal data from a work or a site if the deletion leads to the inability to use the work or site (except in cases of major violations).

The second case was brought in 2016 against the same defendant — the Jameda website. It led to German Supreme Court decision \#VI ZR 34/15 of March 1, $2016^{5}$.

A negative review was published on the defendant's site. The patient was dissatisfied with the quality of the dental services provided to him. The plaintiff (the dentist) was given the lowest score in three categories: (1) treatment, (2) explanation, and (3) trust. The rating was made anonymously, and a review in free form describing the poor quality of services was attached to it.

When the plaintiff found out about the negative review on the site, he sent a letter to the site owner asking him to delete the review or, at least, to give him information about the patient who made it. The plaintiff claimed in his letter that, as far as he could tell, he had never treated such a patient.

After receiving the plaintiff's letter, the site owner contacted the patient and asked him for brief information (2-3 sentences) about the circumstances of the visit and the treatment. The patient provided brief information in three sentences without any supporting documents. After that, the defendant informed the plaintiff that he could neither delete the review nor give any information about the patient's personality. The dentist took the matter to court.

The plaintiff argued that a negative review on three important points for a doctor, posted on a well-known site, violated his personal rights and damaged his business reputation. The plaintiff demanded that the negative rating made by the patient be removed from the respondent's site. The trial court satisfied his claim. The appellate court annulled the decision of the court of first instance and rejected the lawsuit.

The German Supreme Court, considering the cassation appeal, turned to the classical theory of protecting business reputation from inaccurate publications, recalling that there are two types of publications. Some only contain an assessment and cannot be checked for reliability. Others contain a statement of facts and can

${ }^{5}$ Available at: https://dejure.org/dienste/vernetzung/rechtsprechung?Text=VI\%20ZR\%2034\%2 F15\&Suche=VI\%20ZR\%2034\%2F15 (accessed: 17.09.2020) 
be checked for accuracy, which can lead to liability for the dissemination of false information.

In this case, the patient's rating and assessment included two components.

The first was his opinion about the poor quality of treatment. The second was a statement of fact.

The statement about a fact (that the plaintiff had provided dental services to the patient who made the review) could be checked for accuracy.

Further, referring to the duties of the site owner, the court indicated that the latter is not obliged to take measures to verify every review posted on his site. However, if a complaint is received from a person with vested interests, the site owner must take reasonable verification measures.

At the same time, these verification measures should be proportional to the possible violation of the rights of the plaintiff. In this case, a negative assessment on the site could have seriously hurt the interests of the plaintiff by aggravating his competition with colleagues and complicating his further employment. Given the anonymity of the assessment, self-defence, i.e., protection without the help of the site owner, was virtually impossible.

Therefore, after the plaintiff had filed the claim, the site owner should not have limited himself to requesting the person who made the review to write 2-3 sentences about his treatment. The site owner should have tried to get acquainted with documents confirming that perform who left the review had indeed visited this dentist.

As a result, the court of cassation sent the case for new consideration to the court of appeal, specifying that, during the new examination, it was necessary to find out (1) whether the patient who left the review had been treated by the plaintiff and (2) whether the defendant had taken reasonable measures to verify this fact ${ }^{6}$.

The three cases examined above all deal with the same problem: the conflict between freedom of speech and privacy.

The concept of "informational self-determination" formulated in the Spickmich case is significant for the development of judicial practice. It concerns a person's right to determine what exactly should be disclosed about him or herself and in what form.

\section{USA: freedom of speech above all}

In the United States, disputes between specialists evaluated by various sites and the owners of these sites have also been subject to legal proceedings on several oc-

${ }^{6}$ BGH, VI ZR 34/15, March 1, 2016. Available at: http://juris.bundesgerichtshof.de/cgi-bin/ rechtsprechung/document.py?Gericht=bgh\&Art=en\&nr=74291\&pos=0\&anz=1; https://dejure. org/dienste/vernetzung/rechtsprechung?Text=VI\%20ZR\%2034\%2F15\&Suche=VI\%20ZR\%20 34\%2F15 (accessed: 15.09.2020) 
casions. In a few cases, the specialist who received a negative rating knew the person who made it. Such was the case in Dietz Development, LLC v. Perez ${ }^{7}$. The lawsuit was brought directly against the person who had left a negative review on the website. The case involved a client who had hired a contractor to carry out repair work. The client did not like the result of his work and wrote a negative review on the Y. website. The contractor answered on the same site, and the client replied to the comment. By the time the court began to consider the defamation lawsuit filed by the contractor, there were a dozen messages from both parties on the Y. website, and some of the expressions were not acceptable. The court ruled that the parties had mutually insulted each other and denied the claim for damages.

Even more interesting is the case Reit v. Yelp $(2010)^{8}$, which resembles the Jameda case (2014) in its circumstances. A dentist filed a lawsuit against the owner of the Yelp website to receive compensation, restore positive reviews and remove negative reviews from the site, which posted reviews about companies and specialists.

There were ten positive reviews and ten positive ratings about the plaintiff on the Yelp website. Then an unknown person left an anonymous negative review and gave a bad rating, and this negative review automatically deleted all earlier positive reviews [Cheung A., Schultz W., 2018: 325-326]. The plaintiff believed that removing positive reviews after receiving a negative one was the respondent's strategy to motivate professionals to pay for advertising on the site. The defendant did not deny that he offered advertising on the site for money yet drew attention to the fact that the review had been posted by a third party freely and at its own initiative and that the client who left the review had therefore exercised his right to freedom of speech.

The court described in detail the value of the freedom of speech, comparing (as in the Spickmich case) site maintenance activities to journal publishing. The court went even further in its comparison, drawing an analogy between the automatic selection of only the latest reviews and editorial activities. The parties discussed at length on what grounds the "editing" had been carried out: the plaintiff argued that positive reviews were hidden in favour of negative reviews, while the defendant explained that old reviews had been hidden in favour of new reviews.

At the same time, the decisive argument concerned the status of the owner of the site. The content - the response - came not from the owner of the site but from a third party. As the legislation in force at the time of the dispute put the responsibility on the "content provider", the lawsuit was denied.

Moreover, the court emphasized that, even if the defendant had used reviews set aside by third parties for their commercial purposes, this was no reason to restrict the freedom of speech.

7 Dietz Dev., LLC v. Perez, No. CL 2012-16249, 2012 Va. Cir. LEXIS 139 (December 7, 2012), revised, 2012 Va. LEXIS 227 (December 28, 2012). See also: [Cheung A., Schulz W., 2018].

8 Reit v. Yelp!, Inc., 907 N.Y.S.2d 411 (Sup. Ct. 2010). 
Similar circumstances and a similar decision occurred in the case Braverman v. Yelp ${ }^{9}$. However, this approach that, first and foremost, protects the freedom of speech (including anonymous freedom) is open to criticism. If complete freedom is given to anonymous ratings and anonymous reviews written in any form, a person's reputation is essentially in the wrong hands and out of his or her control [Cheung A., Schultz W., 2018: 326, 335].

\section{UK: freedom of speech does not mean freedom of defamation}

In the UK, the key to the legal regulation of the activities of rating sites is considered to be the case Law Society \& Ors v. Kordowski ${ }^{10}$. In 2011, the court decided that the activities of the website "Solicitors from Hell" (solicitorsfromhell.co.uk) were against the law [Scaife L., 2015: 254]. However, the defendants claimed that the site had been created in order to identify and shame unscrupulous solicitors.

The goal of the site shows that it was specially created to collect negative reviews. In order to leave feedback, you had to pay a registration fee. A lot of negative reviews were collected, some of them related not only to the professional activities but also to the identities of solicitors. The plaintiff brought the case as a person acting in the interests of a group of solicitors and law firms in England and Wales. The plaintiffs had found out about posts on the site when they searched for the names of their businesses on Google. The messages and reviews on the site were anonymous.

The court ruled that the personal data of the solicitors had been used without their consent, that the website contained numerous inaccurate and offensive statements, and that it therefore violated the Data Protection Act 1998 (DPA) [Ruhmkorf A., 2014: 55-56].

In addition, the site owners obviously encouraged negative reviews.

Just as in the German Spickmich case, the court drew an analogy with journalist activities and considered the argument that journalists also cite specific names in their publications.

However, this analogy was not in the defendant's favour. Judge Tugendhat stated that "today anyone with access to the Internet can do journalism for free..."

He contrasted the actions of journalists and the actions of the defendant. Journalists cite specific names in their publications when discussing ideas or events

\footnotetext{
9 Braverman v. Yelp, Inc., No. 158299/2013, 2014 WL 712618, at ${ }^{*}$ (N.Y. Sup. Ct. 2014). Cited: Cheung A., Schulz W. Op. cit.

10 The Law Society \& Ors v Kordowski [2011] EWHC 3185 (QB). See: [Ruhmkorf A., 2014: 557-567].

${ }_{11}$ Available at: https://www.bailii.org/ew/cases/EWHC/QB/2011/3185.html(accessed: 16.09.2020)
} 
of importance to society (leading to a prevalence of public over private interests, which is justified), while there was no discussion of socially significant ideas in the activities of the solicitorsfromhell website [Erdos D., 2015: 119-154].

The court conducted a comparative legal review of precedents and the literature and examined recent cases in the United States, where attention had been paid to the freedom of speech, and concluded that, even in the United States, freedom of speech did not mean freedom of defamation. As a result, the court noted that a ban on the further activities of the site would protect the public from deliberately inaccurate information as well as protecting the court from further defamation lawsuits that would undoubtedly be brought if the defendant continued his malicious activities ${ }^{12}$.

The website rateyourlecturer.co.uk, which opened after the closure of solicitorsfromhell.co.uk, also evoked complaints [Ruhmkorf A., 2014: 9].

Therefore, the activity of rating sites is obviously associated with an increased risk of responsibility. At the same time, it seems that the case of the solicitorsfromhell website should not be interpreted as a complete ban on all rating sites, ratings and reviews in the UK. Lawyers, medical doctors, and other professionals who interact with numerous clients should pay attention to feedback, which can be received, in particular, from such sites. Therefore, if the site does not explicitly call for negative reviews, the evaluation of specialists can be recognized as being legitimate, especially if this information is obtained from open sources.

\section{France: anonymous teacher ratings are not good for education}

In France, the court examined a case whose circumstances were very similar to the Spickmich case.

The dispute surrounded the activities of the site note2be.com that provided a forum where students could discuss the professional qualities of teachers and rate them. The French court ruled that this kind of teacher assessment on a site harms the education system ${ }^{13}$, all the more so as the personal data of teachers was being used without their consent [Erdos D., 2015: 16-17]. As a result, an injunction was issued against the further activities of the site.

Our comparative analysis suggests that rating sites are fraught with a conflict between freedom of speech, on the one hand, and privacy, on the other. The boundaries of privacy as a right are not defined for all possible situations ahead of time. It is necessary to evaluate the interests that a rating site protects and the interests that

12 Available at:https://www.bailii.org/ew/cases/EWHC/QB/2011/3185.html(accessed: 16.09.2020)

${ }_{13}$ TGI, 3.03.2008, № RG 08/51650. Available at: http://www.foruminternet.org/specialistes/ veillejuridique/jurisprudence/IMG/pdf/tgi-par20080303.pdf; [Scheuer A., Schweda S., 2011: 13]. 
it jeopardizes and compare them. In any case, information relating to family and personal relationships is more protected than information about professional life. Information relating to professional life is generally open to discussion (provided, of course, that the latter assumes a correct form).

\section{Types of sites}

One can provisionally distinguish two types of rating sites: (1) sites which post consumer reviews of services delivered to them (sold goods, performed work) and (2) sites that publish ratings of personal qualities. The Russian sites "flamp.ru" and "otzovik.com" are examples of the first type. It should be said that these sites have taken reasonable measures to prevent the violation of personal intangible goods.

In particular, the otzovik website has a user agreement that sets down the following obligations: "Users are obliged to refrain from publishing information or other materials that (a) discredit the honour, dignity or business reputation of other users or third parties, (b) contain calls to violence or promote discrimination against people on racial, ethnic, gender, religious or social grounds, or (c) violate the intellectual rights of users or third parties" (clause 4.4) ${ }^{14}$.

An undoubted benefit of such sites is that the information they publish allows potential consumers to receive information about a seller or contractor quickly and easily. Such sites serve as a "low-cost and time-saving means" of assessing the quality of goods and services and are therefore useful to both consumers and society at large [Hinz A., 2011: 745-764]; [Serna F., Inesta J., 2018: 11] ${ }^{15}$.

The opposite of such professional (or "quasi-professional") sites are interpersonal sites, where the object of the assessment is the personal qualities rather than the professional characteristics of an individual. This type of site is, of course, the most dangerous.

For example, it is noteworthy that the Spickmich website (which published reviews about teachers), initially included the evaluation criterion "sexuality, attractiveness". However, this criterion was subsequently removed [Gounalakis G., 2010: 566, 570]; [Ruhmkorf A., 2014: 8, 9].

\section{Conclusion}

The Internet has simplified the dissemination of notes, reviews, and publications as well as facilitating communication. However, it has also made the boundaries of privacy more vulnerable. While the ratings and reviews discussed in this

${ }_{14}$ Available at: https://otzovik.com/term.php (accessed: 15.09. 2020)

${ }_{15}$ Available at: http://www.investigacion-psicopedagogica.org/revista/articulos/24/english/ Art_24_570.pdf (accessed: 9.12.2020) 
article are not the greatest threat to privacy, this area of Internet activity is interesting insofar as it leads to the conflict of different interests such as

the freedom of speech;

the right to privacy;

the interest in obtaining full information about the professional qualities of a specialist or the qualities of a product.

In themselves, ratings are just a means that is neither good nor bad. They existed before the appearance of the Internet (for example, the most popular actor, a best-selling book, etc.).

The advent of the Internet simply made ratings more convenient and accessible. Today, all Internet users have an opportunity to participate in the assessment (rating) process and see the material "traces" of their participation.

There is even a peculiar fashion for ratings today. It is useless (and unnecessary) for legislators to fight this process. The task of legislators and judicial practice is only to set down the acceptable boundaries of these freedoms.

The most important problem for court practice is harmonizing the freedom of speech with the ban on the use of personal data without the consent of the person to whom this data relates.

Almost every rating site that evaluates specialists indicates their first and last name, place of work, and even phone number. The best scenario is when personal data is posted on rating sites only with the consent of the person concerned.

Encroachments on privacy in the name of progress, innovation, and ordered liberty jeopardize the continuing vitality of the intellectual culture that we endorse today [Cohen J., 2013: 1904-1933].

Another important issue is the subject of liability. If a publication containing inaccurate and defamatory information indicates the name of the author, the latter is liable for the publication. However, if it is anonymous, then the only protection option for a person whose intangible benefits it affects is to contact the site owner. The site owner becomes liable only if, after receiving a claim from the person concerned, he does not take reasonable measures to verify the complaint or, after receiving evidence of the inaccuracy of the information specified in the complaint, does not delete the defamatory review and indicate its inaccuracy.

\section{D目 References}

Barendt E. (2016) Anonymous Speech: Literature, Law and Politics. L.: Bloomsbury, 200 p.

Cheung A., Schulz W. (2018) Reputation Protection on Online Rating Sites. Stanford Technology Law Review, no 21, pp. 322-326.

Cohen J. (2013) What Privacy is For. Harvard Law Review, vol.126, pp. 19041933. 
Erdos D. (2018) Intermediary publishers and European data protection: Delimiting the ambit of responsibility for third-party rights through a synthetic interpretation of the EU acquisition. International Journal of Law and Information Technology, vol. 26, pp. 189-225. Available at: https://academic.oup.com/ijlit/ article-abstract/26/3/189/5033541 (accessed: 09.08.2019)

Erdos D. (2015) From the Scylla of Restriction to the Charybdis of License? Exploring the Present and Future Scope of the Special Purposes' Freedom of Expression Shield in European Data Protection. Common Market Law Review, vol. 52, pp. 119-154.

Hinz A. (2011) Attitudes of German Teachers and Students towards Public Online Ratings of Teaching Quality. Electronic Journal of Research in Educational Psychology, no 24, pp. 745-764. Available at: http://www.investigacion-psicopedagogica.org/revista/articulos/24/english/Art_24_570.pdf. (accessed: 19.12.2019)

Roessler B. (2005) The Value of Privacy. Cambridge: Polity Press, 288 p.

Ruhmkorf A. (2014) Ratemylegalrisk.com - The Legality of Online Rating Sites Relating to Individuals in Data Protection Law. Intellectual Property Forum, vol. 96, pp. 8-9, 55-67.

Scaife L. (2015) Handbook of Social Media and the Law. N.Y.: Informa Law, 388 p.

Scheuer A., Schweda S. (2011) The Protection of Personal Data and the Media. Limits to the Use of Personal Data, no 6, pp. 7-28.

Schoeman F. (1992) Privacy and Social Freedom. Cambridge: Cambridge University Press, $240 \mathrm{p}$.

Schulz W. (2018) Regulating Intermediaries to Protect Privacy Online - the Case of the German NetzDG. HIIG Discussion Paper Series, 2018-01. Available at: https://www.hiig.de/wp-content/uploads/2018/07/SSRN-id3216572.pdf. (accessed: 11.12.2019)

Serna F., Iniesta J. (2018) The delimitation of freedom of speech on the Internet: the confrontation of rights and digital censorship. Available at: https://pdfs. semanticscholar.org/6220/95b49c43687ba4766e1888f5bbdaa46559c5.pdf? ga=2.69714838.764201525.1565323822-198308019. 1565323822 (accessed: 11.12.2019)

Strahilevitz L. (2008) Reputation Nation: Law in an Era of Ubiquitous Personal Information. NW. L. Rev., vol. 102, pp. 1668-1738.

Ungern-Sternberg S. (2019) Demokratische Meinungsbildung und künstliche Intelligenz (Democracy, Public Opinion Formation, and Artificial Intelligence). In: Antje von Ungern-Sternberg S. Demokratie und Künstliche Intelligenz. Tübingen: Mohr Siebeck, pp. 1-28. Available at https://papers.ssrn.com/sol3/papers.cfm?abstract_id=3400756 (accessed: 11.12 .2019 ) 